\title{
ACCOMODATION STRATEGY IN BUYING AND SELLING CONVERSATIONS AT GANG BARU TRADITIONAL MARKET CHINATOWN SEMARANG
}

\author{
Catur Kepirianto Kepirianto ${ }^{1}$, Soepomo Poedjosoedarmo ${ }^{2}$, Suhandano ${ }^{3}$ \\ English Department, Faculty of Humanities, Diponegoro University, Semarang, Indonesia. \\ Humanities Postgraduate Study Program, Faculty of Cultural Science, Universitas Gadjah \\ Mada, Yogyakarta, Indonesia ${ }^{2}$. Indonesian Department, Faculty of Cultural Science, \\ Universitas Gadjah Mada, Yogyakarta, Indonesia ${ }^{3}$. \\ caturkepirianto@live.undip.ac.id ${ }^{1 *}$
}

\begin{abstract}
Language is a means of communication to convey idea, mind, and feeling to the other. The research problem is the strategy applied by buyers and sellers at Gang Baru traditional market Chinatown Semarang. This research applies the descriptive qualitative method. To collect data, the writer applied observation, tapping, and recording. Then the data were analyzed descriptively based on the theory of accommodation. The results show that there is an accomodation in the conversation between buyers and sellers in traditional market Chinatown Semarang. The direction of accommodation are both convergence and divergence. In the convergence, the speakers adapt positively, while in the divergence, the speakers adapt negatively. The interpersonal interaction provides the speech in a conversation. Each talk or speech has its own function and becomes the component to arrange the comprehensive relation in a conversation. There are functions on convergence and divergence accommodation. The convergence accommodation has functions to maintain the symmetric speech, to reactualize the solidarity, to keep cooperative speech, to reduce interpersonal difference, to consider the other view, and to provide adaptation. While the divergence accommodation has functions to bargain, to retain the argument, to keep personal speech, to maintain the identity, to keep personal identity, to maintain ethnic identity, to retain the distance, to keep asymmetric speech, and to maintain idiosyncratic speech. It is implied that the speech accommodation in Gang Baru traditional market Chinatown Semarang represents such markers as solidarity, cooperative, symmetric, asymmetric, tolerant, identity, and ethnic markers.
\end{abstract}

Keywords: accommodation; Chinatown Semarang; convergence; divergence; traditional market

\section{Introduction}

Language is a means of communication that is used by the community to convey ideas, thoughts, and feelings (Poedjosoedarmo, 2001: 169; Poedjosoedarmo, et al., 2002: 7). Language in its form, function, and meaning is used to show the difference of the expression between one speaker and another speaker in their daily life. (Wardaugh, 1988: 10; Searl, 1969: 3).

Gang Baru traditional market is the only traditional market in Semarang's Chinatown. This traditional market is a place of intensive conversation between sellers and buyers in trading activities. The seller and buyer hold a conversation through bargaining the price to obtain merchandise. The buying and selling conversation in the form of bargaining can be short or long expression to reach a price agreement. In a bargaining conversation, the seller tries to offer and sell their merchandise at the highest price, while the buyer tries to buy the merchandise at the lowest possible price and the best quality of goods. The seller hopes that the goods sold out will sell well and quickly, on the other hand the buyer hopes to get the goods he needs soon. 
In an oral conversation, the speech accommodation can occur simultaneously (Pickar, 1970: 360; Holland, et al., 1999: 68). On the speech accommodation, there is the act of interpersonal adaptation between one speaker and another speaker (Giles, et al., 2007: 51; Austin, 1980: 94; Ervin-Tripp, 1986: 226; Poedjosoedarmo, 2017). This action is an attempt of the speech participants to adapt to each other, which can be in the form of convergence adaptation or divergence adaptation. In convergence adaptation, an individual makes a positive adaptation to each other and prioritizes equality with others. However in divergence adaptation, an individual adapts negatively, which is an attempt to move away from one another and prioritize differences from others. The problem in this study is whether there is accommodation in the buying and selling conversation in Gang Baru traditional market Semarang's Chinatown. The other problem in this study is about how the direction of accommodation occurs. Therefore the purpose of this study is to describe and explain the speech accommodation and the direction of accommodation in the buying and selling conversation between sellers and buyers in Gang Baru traditional market that the site is at Chinatown Semarang.

\section{Research Method}

This study applied a descriptive qualitative research method. This method was applied to obtain a description and explanation of the nature or characteristics of the actual data and it was hoped that it would be able to see the factors underlying the properties of the data obtained (Koentjaraningrat, 1990: 26; Sugiyono, 2012: 15). The collecting data was held through observation, recording, simak libat cakap and simak bebas libat cakap.

In collecting the data, the researcher observed and listened to the speech interaction and conversation between sellers and buyers along the 500 meter-long coridor at Gang Baru traditional market Chinatown Semarang. While observing and listening to the interaction, the researcher recorded and took the notes about the participants, the locations, and the circumstances of the speech interaction and conversation between the seller and the buyer. The researcher also recorded the context of the situation where the conversation between the seller and the buyer occured.

Data analysis of the study was carried out inductively (Koentjaraningrat, 1990: 9). It is conducted to obtain the phenomenon of accommodation in the speech interactions and conversations between sellers and buyers. The collected data was then analyzed to find out whether there was the act of accommodation and how the direction of accommodation was in the speech interactions and conversations between sellers and buyers in the traditional market along Gang Baru path in Chinatown Semarang (Budiman, 1978: 9; Daradjadi, 2013: 53).

\section{Finding and Discussion}

Based on the data obtained, the findings and results of data analysis in this study indicate that there is the act of accommodation in the speech interaction and conversation between sellers and buyers in Gang Baru traditional market Chinatown Semarang. The accommodation in this research is the act of interpersonal adaptation in communicative interactions between sellers and buyers. The direction of accommodation in the speech 
interaction and conversation between seller and buyer in traditional market is convergent accommodation and divergent accommodation.

Table 1. The accommodation

\begin{tabular}{cc}
\hline \hline \multicolumn{2}{c}{ Accommodation } \\
\hline \hline $\begin{array}{c}\text { Convergence } \\
\text { individual strategy to } \\
\text { adapt in a conversation } \\
\text { to a close direction and } \\
\text { to adapt positively. }\end{array}$ & $\begin{array}{r}\text { individual strategy to } \\
\text { to keep apart and to } \\
\text { adapt negatively. }\end{array}$ \\
\hline \hline
\end{tabular}

Source: Giles, et al. (2007: 8-15)

The above table informs that there are two directions of the accommodation: convergence and divergence accommodation. Convergence accommodation is the act of accommodation in which an individual applies particular strategy to adapt in a conversation to a close direction and to adapt positively. While divergence accommodation is the act of accommodation in which an individual applies particular strategy to adapt in a conversation to keep apart and to adapt negatively.

Furthermore Giles, et al. (2007: 11) provides some principal distinctions in characterizing convergence and divergence as in the following table.

Table 2. Distinctions in characterizing convergence and divergence

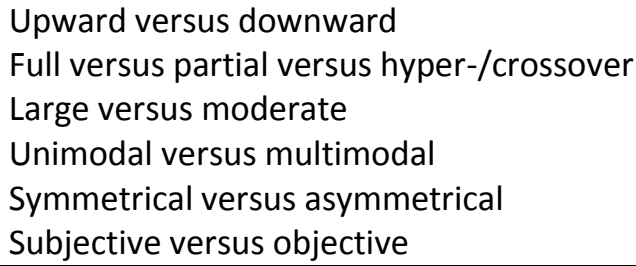

Source: Giles, et al. (2007: 11)

\section{Convergence accommodation}

Convergence accommodation is an individual strategy to adapt in a conversation to a close direction and to adapt positively (Giles, et al., 2007: 2). The purpose of convergence accommodation is to reduce interpersonal difference.

The accommodation of convergence in the speech interaction and conversation between sellers and buyers in Gang Baru traditional market Chinatown Semarang generally takes place either at the beginning of a conversation or at the end of a conversation. At the beginning and the end of the conversation, the seller and buyer try to make a convergence adaptation, in which they approach each other and the adaptation occurs positively because the speech of the participants, the seller and buyer have the same purpose. They need to reach the similarities. They particularly reduce the personal difference. The seller needs the 
buyer and on the other hand the buyer needs the seller. The participants try to adap positively. The participants try to make suitable and similarities for use, need, or situation.

The seller rightly needs a buyer because the seller has merchandise to sell immediately to the buyer in a traditional market. The merchandise sold out by the buyer in Gang Baru traditional market is the product of agricultural and livestock commodities which are generally in a wet state, have a high water content, so that the age of the merchandise is relatively short and can be easily damaged if it is not immediately sold out. Moreover there is no means of preservation likes refrigerator or any tools to preserve the products. The goods and merchandise from agricultural and livestock commodities are vegetables, tofu-soybean curd, tempeh-fermented soybean cake, fruits, meat, eggs, and fish.

In order for merchandise to be sold immediately, sellers always try and use their speech strategies so that merchandise sells quickly and runs out quickly. The seller is always trying to get buyers interested in the merchandise and then the buyer buys the merchandise at the highest price and as much as possible. The buyer and seller always try to purchase their products in the high quantity and quality. The seller hopes that his merchandise is sold out as soon as possible and in the shortest possible time. In addition, the seller also hopes to get the highest profit. Therefore, sellers in traditional markets always try to get closer to buyers by greeting and affecting buyers, offering goods, showing merchandise, asking for items needed, or explaining the advantage of the product, the ingredients of a recipe, the procedure to cook a menu, serving direction, composition of the menu, how to consume, or suggested preparation. Buyers also carry out convergence accommodation since the buyers basically also need sellers who want and need to sell their goods and products through bargaining. Buyers in traditional market also have desire and feel like to buy merchandise that can be negotiable or there would be bargaining so that buyers can obtain merchandise at a cheaper price than buying in supermarket or modern market. In principle, the buyer wants to buy the goods and products needed at the lowest possible price and the buyer can also obtain the goods needed with the highest quality.

The speech participants, both sellers and buyers naturally try to greet each other and show the same interests. In this situation, the seller try to offer goods and products and the buyer applies respond to the offer. The seller shows the items to be sold and the buyer sees and pays attention to the items the seller shows and promotes.

At the end of the conversation, there is usually a price agreement between the seller and the buyer (Baryadi, 2001: 5). The speech and expression of the two participants-the seller and buyer provide agreement and approval to accept the price well. Then the seller hands over the goods and products or merchandise to the buyer. As a consequence the buyer then gives an amount of money according to the agreed price. After that, the seller and buyer express their thanks and gratitude to each other and say goodbye. The following is an example of data on buying and selling speech interaction and conversation between a seller and a buyer who are traditionally getting a trade and commerce in Gang Baru traditional market Chinatown Semarang that shows the existence of convergence accommodation.

\section{Context:}


A 34-year-old Javanese woman seller and a 37-year- Chinese descent woman buyer in a fresh fish trade conversation in a stall which is full of various fish in the traditional market in Gang Baru area of Semarang's Chinatown.

(1) S : Cik, iki lho delok o. Aku duwe barang ayu-ayu. Wis, mesti

Tacike seneng.

'Ma'am, please look into this well. I have a nice thing. Of course, Sis will be satisfied.'

(2) B : Apa kuwi?

'What's that?'

(3) S : Gurami.

'Gurami, fresh-water carp.'

(4) B : Mana? Da mana barange? 'Where? Where is it?'

(5) S : Tu.. ditong.

'That's.. in a bucket.'

(6) B : Mana ta?

'Where is it?'

(7) S : Tong biru.. deket criping.

'Blue bucket.. near criping, round-flat shell.'

(8) B : Tak liak-liak dulu, ya?

'I need to see first, OK?'

(9) S : Ya. Ini masih hidup semua.

Seger-seger.. wong baru aja

dikirim.

'Well. They are all alive. All

fresh.. have already been

delivered.'

Notes: $\mathrm{S}=$ Seller, $\mathrm{B}=$ Buyer

In the data of a conversation above, the seller and buyer try to adapt each other and there is a speech transaction. According to Giles, et al. (2007: 3), the conversation above whose speech is complementary or mutually adaptive is an accommodation of convergence.

In data (1), seller tries to adapt the buyer. Seller addresses the buyer with the address term, Cik ' $\mathrm{Ma}^{\prime} \mathrm{am}^{\prime}$ '. Then seller asks the buyer to look into the fish throughly. Then seller shows the fish to buyer that she has fresh and good fish through the expression Aku duwe barang ayu-ayu. 'I have a nice thing.' The expression has function to show the buyer that the seller has good and fresh fish. So this expression unconsciously has function to accomodate the seller about the nice and fresh fish condition. The buyer in data (2) asks the thing that is exposed by the seller and the seller in data (3) directly answers the buyer that the thing is gurami, the fresh-water carp. The previous speech interaction between a seller and a buyer reflects a good interpersonal relationship. The speakers keep a cooperative speech. 
Data (4) and (5) are the question and answer about the location of the fish. The buyer pretends that she still does not know the fish location. As a consequence, the seller will show her the fish and its location. Otherwise the buyer still need understanding the fish location. Therefore the seller in data (7) answers directly and gets more detail information about the fish location. After getting the detail information about the fish location, the buyer then asks permission to look into the fish throughly. This speech interaction rightly has function to check the real condition of the fish. The seller in data (9) always convinces and assures the buyer about the fresh condition of the fish.

Those expressions in a conversation between seller and buyer convince that there is a positive accomodation. The seller and buyer accommodate each other. The seller and buyer adapt positively on their conversation. The above speech conversation seems to maintain the symmetric speech well. The following data provide the convergence accommodation in a conversation between a seller and a buyer after bargaining the commodities in Gang Baru traditional market Chinatown Semarang.

(10) : Bisa dicoba, Cik.

S 'You can try, ma'am.' (Buyer tastes the orange fruit that has been provided and opened by the seller.)

(11) : Ya, legiok. 'Yes, it's sweety.'

(12) : Lha wong dodolanku, ya mesti legi. Kaya sing dodol, ya Cik. Ra bakal keliru.

'That is my merchandise, it must be sweet, like the seller, yes ma'am. Of course it won't be wrong. '

Notes: $\mathrm{S}=$ Seller, $\mathrm{B}=$ Buyer

The conversation above shows that there is an interpersonal act in the form of adaptation to a positive adaptation between the seller and the buyer. On those speech interaction, the seller and the buyer make a convergence accommodation. The seller in data (10) tries to convince the buyer about the quality of the goods and products by offering the merchandise to the buyer to try the taste of the fruit she is selling, as in the speech data (10) Bisa dicoba, Cik. 'You can try, ma'am.' Data (11) is the buyer's response to the seller's offer to try the fruit being sold. According to the buyer, it turns out that the fruit offered by the seller is right, that is, it has good quality and tastes sweet, as the buyer said in the data (11) $Y a$, legi ok. 'Yes, it's sweety.' Thus, the conversation in data (10) and (11) is a conversation offer from the seller so that the buyer tastes her merchandise and the offer is positively responded by the buyer regarding to the truth of the quality of the fruit being sold. The previous data rightly reactualize the solidarity between the speakers.

The conversation and data above also shows that in speech (12) the seller exaggerates the quality of her merchandise. The seller assures the buyer that the merchandise she sells must be of good quality, that is sweet and it of course will be 
disappointed the buyer. The buyer will not get errors when buying fruit on her. The utterance is intentional by the seller to convince the consumer with the purpose that the buyer is interested in buying merchandise at the stall he is selling. The above expression actually considers the other view and reduces interpersonal difference.

The following is a conversation between the buyer and seller about the price of the merchandise.

(14) : Ya udah tuk pelarisan.

'It's okay for a quick-selling.'

(15) Ini uangnya.

B 'It's the money.'

(16) Iya. Kamsia.

S 'Yes. Thank you.'

(17) Terima kasih.

B 'Thank you.'

Notes: $\mathrm{S}=$ Seller, $\mathrm{B}=$ Buyer

Data (13) and (14) provide a conversation between a buyer and a seller. The buyer bargains on a fixed price, that is $\mathrm{Rp} 12.000,-$. The buyer then gives respond by agreeing the price proposed by a seller. On the next turn, the seller informs that the price stated becomes the preliminary selling and it is convinced and has function as the firts item sold in a work day. It is hoped that it will affect and stimulate for the later sales. It also implies that the price that is reached and agreed will make the next successful trade. It means that the interaction provides the satisfaction and keeps symmetric ideas. Finally, the buyer gives the amount of money. The seller receives the money and both the buyer and seller says thanks each other. The above interaction reflects that the speakers tries to provide adaptation nicely.

The following conversation is an example of convergence accommodation about the agreement of price in a closing interaction between a buyer and a seller in traditional market.

(18) : Nggih. Niki kalih kilo rong ons. Dadose tiga kalih gangsal atus. 'Yes. It's two kilos and two ounces. So they're thirty two (thousand) and five hundred rupiahs.'

(19) : Mbok dipaske telu loro?

'How's about thirty two (thousand) only?'

(20) : Nggih pun.. kangge lengganan. Ini Cik. Makasih, ya.

'It's OK.. it's for subscriber. This's ma'am. Thank you.'

(21) : Kamsia, ya. 
'Well, thank you.'

: Nggih sami-sami.

'You're welcome.'

Notes: $\mathrm{S}=$ Seller, $\mathrm{B}=$ Buyer

The conversation in the data above is the interaction of buying and selling conversation between a Javanese-woman seller and a Chinese-descent-woman buyer. The speech above is so intense, phenomenal, and unique because the speech code that occurs is full of code mixing, consists of Javanese speech code, informal Indonesian variety, and Chinese lexicon. The community in Gang Baru traditional market Semarang's Chinatown is heterogeneous, multiethnic, multilingual, and multicultural participants. The participants express multilingual interaction. They are from multiethnic background.

The participants on data (18) - (22) are a seller of Javanese woman aged 34 years and a buyer of Chinese-descent woman aged 37 years. The speech codes are multilingual, covering the local language of Javanese, both Javanese Ngoko ( $\mathrm{L}=\mathrm{low}$ ) and Javanese Krama $(\mathrm{H}=\mathrm{high})$, the national language of informal Indonesian variety, and the lexicon of the people of Chinese descent in Semarang (Ferguson, 1959: 331; Poedjosoedarmo, 1968: 61; Poedjosoedarmo, et al., 1979: 24; Poedjosoedarmo, et al., 1982: 30; Poedjosoedarmo, et al., 2002: 29).

The seller expresses her idea at the end of the conversation, which was mostly in the form of Javanese krama $(\mathrm{H})$ speech code which is intended to confirm what the buyer expected, Nggih. Niki kalih kilo rong ons. 'Yes. It's two kilos and two ounces.' Dadose tiga kalih gangsal atus. 'So, they're thirty two (thousand) and five hundred rupiahs.' Nggih pun.. kangge lengganan. 'It's OK.. it's for subscriber.'; and Nggih sami-sami. 'Yes, you're welcome.' All of the speech codes are Javanese speech codes that function to be polite to the speech partner (Poedjosoedarmo, 1978: 13).

The seller's speech in the form of the Indonesian speech code is Ini. 'This is.' and Makasih ya. 'Well, thank you.' While the seller's speech in the form of Chinese speech codes is a greeting for adult woman refers to a Chinese-descent buyer. The address term is Cik 'Ma'am'. At the end of the conversation and after the price transaction is agreed upon, the seller asks for providing additive service so that the buyer feels satisfied and then the buyer will become a loyal customer. Therefore the buyer always tries to establish good relation with the seller. The buyer also hopes to be familiar with the seller and as a consequence, the next day when going shopping again, the buyer will not get a high price. Moreover the buyer at least will get a fair price and even get a cheap price.

To close the speech, the speakers-the seller and the buyer are satisfied and the price agreement was reached finally. Then the conversation ends with the act of handing the money and receiving the items, and finally continuing to express mutual thanks. Those interaction actually reflects the function of an interaction that is expressing the solidarity and keeps cooperative acts.

The bargaining price agreement that is occurred and the thank's expression in the speech conversation between the seller and buyer shows that in the conversation above, the speech adaptation takes place in a positive direction. That is convergence 
accommodation. Based on the above explaination, Table 3 provides the functions of convergence accommodation as follows.

Table 3. Convergence accommodation and its functions

Functions of convergence accommodation

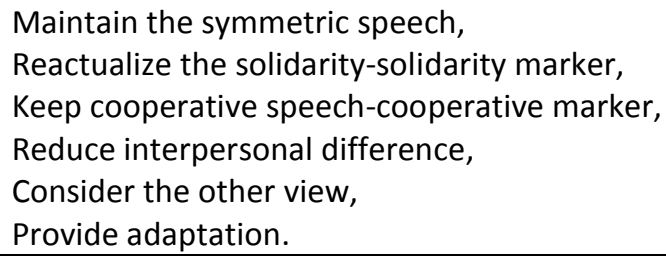

\section{Divergence accommodation}

Divergence accommodation is an individual strategy to adapt negatively on a speech interaction and conversation. The direction of the divergence accommodation does not close by each other rather than it keeps at a distance from each other, or it adapts in a negative manner (Giles, et al., 2007: 8). Divergence accommodation maintains the differences and does not accomodate the symmetric relation between the speakers. Table 4 provides the divergence accommodation and its functions.

\section{Table 4. Divergence accommodation and its functions}

Functions of divergence accommodation

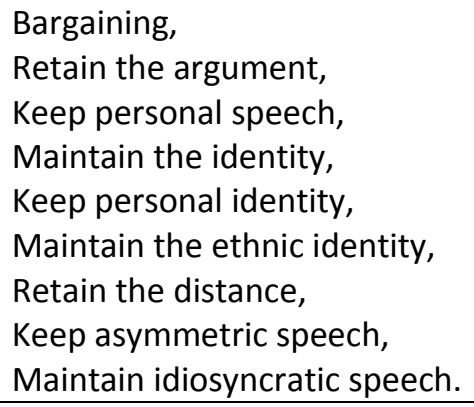

The following is an example of conversation data that shows the existence of divergence accommodation.

(23) : Cik, rene ta Cik, wis suwe ora mampir.

'Ma'am, come in, please Ma'am.. you never stopped by for a long time.'

(24) : Ra ana dhuwit.

'No money.'

Notes: $\mathrm{S}=$ Seller, $\mathrm{B}=$ Buyer

In data (23) and (24), a seller-a Javanese woman addresses a buyer-a Chinese woman with the Chinese address term Cik, 'Ma'am'. The seller adapts on the buyer's culture on 
addressing and asks the buyer to stop by at her stall. She also reminds the buyer not coming by for a long time, Cik, rene ta Cik, wis suwe ora mampir. Ma'am, come in, please Ma'am.. you never stopped by for a long time.' Otherwise, the buyer respons negatively to stop by and expreses the reason that she has no money, Ra ana dhuwit. 'No money.' It seems that the buyer adapts in a contradictory manner. The buyer tries to make a distance because the seller usually asks her to buy her commodities. This distance strategy by the buyer represents the divergence accommodation.

In data (25) and (26), a seller persuades the buyer to stop by and take a look at the merchandise she has for the reason that she has not bought his goods and products for a long time.

(25) : Wis rene ta, ndelok-ndelok sik, wong wis suwe ora numbasi.

'Okay.. come in, please, just seeing is OK, you never bought me for a long time.'

(26) : Piye ta. Ndak isa. Minggu lalu aja misih mrene, Iho. Aku ambik itu... apa tu?

'How is it? It's not true. Just last week, I still arrived here. I bought something.. what's that?'

Itu Iho, sing ada item-iteme. Ah, apa ta uwi? O, ya iwak nus.

'That's it.. has black one. Ah.. What's that? Oh yes.. flat-headed squid.'

Genah tuku noban, malah mbok keki sak ekrak amoh, ngono.

'Rightly I bought twenty thousand rupiahs, instead having abundant quantity.'

Notes: $\mathrm{S}=$ Seller, $\mathrm{B}=$ Buyer

In the conversation above (26), the buyer responds by rejecting the seller's invitation, Ndak isa. 'No.'It isn't.' to stop by and buy the merchandise. Because buyers still remember that last week she bough amount of flat-headed squid. Negative respond (Ndak isa.' (t isn't.') and the reason that she had bought flat-headed squid expressed by the buyer conveys the divergence accommodation.

The following data express an asymmetric speech between a seller and a buyer about the fish condition.

: Wis ta Cik, kula pendhetke sing apik-apik. 'OK Ma'am, I'll get a good one.'

(28) : Ikane sak upil-upil ngono, kok. 'The fish is too small, isn't it?'

(29) : Apa ta Cik. Wong gurami 
gedhene ngene kok mbok arani

sak upil. Trus irunge sepira.

'What d'you mean? The gurami is

so big.. why d'you mind it small.

Then how big is the nose?'

Notes: $\mathrm{S}=$ Seller, $\mathrm{B}=$ Buyer

The seller wants to show a fresh and large-sized fish to the buyer. But the seller's desire is denied by the buyer's expression with the opposite meaning. The seller states that the fish are fresh and large, while the buyer states asymmetric respond and it means contradictory. Actually the fish shown to the buyer is not large or it is small, Ikane sak upilupil ngono, kok. 'The fish is too small, isn't it?' Then the seller explains more about the actual size of the indicated gouramy. The seller tries to convince the buyer that the fish are large, not small. Asymmetric utterances delivered by sellers and buyers (Ikane sak upil-upil; wong gurami gedhene ngene kok mbok arani sak upil. 'The gurami is so big.. why d'you mind it small.') indicate that each speaker tries to express asymmetrically to show that the speech is negative or opposite adaptation. Such speech is a divergence accommodation utterance.

Implications of the asymmetric speech in the above buying-selling conversation in traditional market has a function that the seller wants to convey the fish condition that the fish are in a good condition and it is large in quantity so that the puchasing price can be high, while the buyer wants to express that with decreasing fish size, the fish price will be cheaper. Thus the seller and buyer actually have the principle to maximize their respective profits.

In the following conversation data, the seller and buyer also state the asymmetric expression.

Lho Cik, njenengan liat. Lemulemu sak gajah ngeten, kok. 'Ah Ma'am, please watch it. It's big, as big as elephant.'

: Tapi daginge tipis-tipis nok. 'But the flesh is thin. Uh.'

: Eh, Cik. Kok ndak percaya, ta.

'Uh Ma'am. Why don't you believe it.'

Notes: $\mathrm{S}=$ Seller, $\mathrm{B}=$ Buyer

The seller assures the buyer by directly showing the fish to the buyer that the fish is large. The seller even convinces the buyer that the fish is large by comparing the size of the fish with the size of an elephant. This comparison is done by the seller to convince buyer that the fish is as large as elephants. Therefore the fish is not as small. Elephant is an animal whose referent is considered the largest. So something that has the size of an elephant, there will be intention that the object is large in size. The speech topic of a fish as big as an elephant means that the fish is large.

The following data is a speech conversation between the seller and buyer regarding the nominal price and condition of the fish being sold. 
'How much price's a kilo?'

: Dua lapan, pas.

'Twenty eight, fixed.'

(35) : Ah, mahal banget. Katane dua lima.

'Ah, too expensive. The rumor.. twenty five.'

(36) : Dua lima tu, nek mati. Lha ini hidup dan seger-seger Iho, Cik.

'Twenty five for a dead one. It's still alive and fresh, Ma'am.'

Notes: $\mathrm{S}=$ Seller, $\mathrm{B}=$ Buyer

Data (33) and (34) consist of questions and answers about the price and size of the scales. Data (35) is the expression and the response of a buyer to the price delivered by the seller. The buyer feels that the price of fish is high while the buyer conveys the opposite price, which is lower. Then the seller in the data (36) gives an explanation that the nominal price delivered by the buyer is the price of fish that is dead, not alive. Whereas the fish that the buyer sells are alive and not dead, so the seller's price is different from the price delivered by the buyer. Fish that are alive and in a fresh condition are relatively higher in price than the dead and unfresh fish.

Speech in data (36) is the seller's explanation of the nominal price in relation to the condition of the fish that are alive. The seller in the speech has a function to increase the purchasing power expressed by the buyer. The speech also serves to deny the buyer's speech that the nominal price of the fish is very expensive.

Expression on the conversation above (Ah, mahal banget. 'Ah, too expensive.') is a speech that aims to downward the price delivered by the seller. The downward expression has a function to decrease the fixed price delivered by the seller, Dua lapan, pas. 'Twenty eight thousand rupiahs, fixed.' The buyer actually hopes that the price of the fish is lower like the information she received, Katane dua lima. 'The rumor.. twenty five thousand rupiahs.' That is the expression of the buyer who delivered a nominal price lower than the nominal price previously delivered by the seller. It means that the seller wants to reduce the price that was delivered. Thus the statement Ah, mahal banget. 'Ah, too expensive.' that the buyer expressed is a feature of speech aimed at downward. Speech aims at downward are divergent accommodation utterances.

The following is a conversation on the selling-buying speech between seller and buyer in Gang Baru traditional market Chinatown Semarang about the need to raise prices.

: Dah, tak tambahi dua anem, ya?

'Yeah, I add.. become twenty six, right?'

: Tambahi neh, Cik. Aku ra untung, ki.

'Add more price, Ma'am. I have no profit then.'

Notes: $\mathrm{S}=$ Seller, $\mathrm{B}=$ Buyer 
The buyer in data (37) states the ability to increase the nominal price, Dah, tak tambahi dua anem, ya? 'Add more price, Ma'am.' The seller also adds that if the price is not raised, then the seller feels no profit. Aku ra untung, ki. 'I have no profit then.' The statement ra untung, 'no profit' is a downward expression. Though this expression has function to support the buyer to increase the price. The downward expression, ra untung, 'no profit' contains the word 'no' as a negative lexicon. It implies that the downward expression is a convergence accommodation.

The following conversation is about bargaining for which the price has not yet been agreed. Seller and buyer insist on the nominal price of each (fixed price). To open the fixed price, the buyer applies a certain strategy.

(39) : Wis, tak paske. Dua tujuh, ya?

'Well, it's fixed. Twenty seven, huh?

(40) : Hargane wis pas, kok Cik. 'The price was fixed, Ma'am.'

(41) : Wis, ah. Regamu larang. Ndak isa turun. Tak tinggal sik, ya?

'Huh. The price is expensive. It can't go down. May I leave, huh?

Notes: $\mathrm{S}=$ Seller, $\mathrm{B}=$ Buyer

Data (39) and (40) show that the buyer and seller have determined a fixed price, Wis, tak paske. Dua tujuh, ya? 'Well, it's fixed. Twenty seven, huh?' The other expression is Hargane wis pas, kok Cik. 'The price was fixed, Ma'am.' The price is fixed. Price is unchanged, fixed. Nobody cannot raise or lower the prices. It means that the speech is asymmetric, not symmetric, so the price has not yet been agreed. The situation shows that the seller and buyer maintain divergence accommodation. Seller and buyer persist with her price that is fixed. The buyer does not want to reduce the nominal price and the buyer does not want to increase the price. So that there is static convergence accommodation.

To break the fixed price, the buyer applies a new strategy, which is to leave the seller and does not continue the transaction. It applies two reasons, first, the selling price set by the seller is still high, Regamu larang. 'The price is high or too expensive.' The next reason is the price cannot decrease, Ndak isa turun. 'The price cannot be reduced.' Those two buyer's expressions hopefully provide speech function to downward the situation and go down the price. It implies that there is a negative adaptation, a divergence accommodation.

Then the buyer decides not to increase the price rather than she left the bargaining, Tak tinggal sik, ya. 'I left then.' In spite of the fact that it will affect the seller to remind the fixed price. It is an asymmetric strategy applied by the buyer that affects the seller. Finally the seller agrees to change the fixed price and receive the buyer's price. The downward and asymmetric strategies successfully shift and modify the buyer to decrease the fixed price. It is a successful divergence accommodation to change the price.

\section{Conclusion}

Based on the previous explaination, it can be concluded that there is an accomodation in the conversation between buyer and seller in traditional market Chinatown Semarang. The 
accommodation are convergence and divergence. In the convergence, the speakers adapt positively, otherwise in the divergence, the speakers adapt negatively. The interpersonal interaction provides the speech in a conversation. Each talk or speech has its own function and becomes the component to arrange the comprehensive relation in a conversation.

There are functions on convergence and divergence accommodation. The convergence accommodation has functions to maintain the symmetric speech, to reactualize the solidarity, to keep cooperative speech, to reduce interpersonal difference, to consider the other view, and to provide adaptation. While the divergence accommodation has functions to bargain, to retain the argument, to keep personal speech, to maintain the identity, to keep personal identity, to maintain ethnic identity, to retain the distance, to keep asymmetric speech, and to maintain idiosyncratic speech.

It is implied that the speech accommodation in Gang Baru traditional market Chinatown Semarang represents such markers as solidarity, cooperative, symmetric, tolerant, asymmetric, identity, and ethnic markers.

\section{Acknowledgement}

This article is a part of the research funded by Ditlitabmas Dikti Kemendikbud-BOPTN through DIPA UNDIP 2014 No. 023.04.02.189185/2014. The idea is from the dissertation of Catur Kepirianto (2019), Universitas Gadjah Mada, Yogyakarta, Indonesia.

\section{References}

Baryadi, Praptomo. (2001). Konsep-konsep Pokok dalam Analisis Wacana. in Jurnal Widyaparwa No. 57, p. 1-23. Yogyakarta: Balai Penelitian Bahasa.

Budiman, Amen. (1978). Semarang Riwayatmu Dulu. Jilid Pertama. Semarang: Tanjung Sari.

Daradjadi. (2013). Geger Pacinan 1740-1743: Persekutuan Tionghoa-Jawa Melawan VOC. Jakarta: Penerbit Buku Kompas.

Ervin-Trip, S.M. (1986). Sociolinguistics Rules of Address. in Sociolinguistics: Selected Readings. J.B. Pride dan Janet Holmes. p. 225-240.

Ferguson, Charles A. (1959). Diglossia. in Word, Vol. 15, p. 325-340.

Giles et al. (2007). Contexts of Accommodation: Studies in Emotion \& Social Interaction. Cambridge: Cambridge University Press.

Holland et al. (1999). Ethnic Consumer Reaction to Targeted Marketing: A Theory of Intercultural Accommodation. In Journal of Advertising, Vol. 28, No. 1, Genderand Multicultural Issues (Spring), p. 65-77, M.E. Sharpe, Inc.

Kepirianto, Catur. (2019). "Bahasa dalam Ranah Jual-Beli di Pasar Tradisional Gang Baru Kawasan Pecinan Semarang." Unpublished Dissertation. Universitas Gadjah Mada, Yogyakarta.

Koentjaraningrat. (1990). Metode-Metode Penelitian Masyarakat. Jakarta: PT Gramedia

Pickar, Gertrude B. (1970). Martin Walser: The Hero of Accommodation. in Monatshefte, Vol. 62, No. 4 (Winter), p. 357-366. Wisconsin: University of Wisconsin Press. 
Poedjosoedarmo, Soepomo, and Wolff, John U. (2002). Communicative Codes in Central Java. Data Papers Series, Number 116. Ithaca, New York: Cornell Southeast Asia Program.

Poedjosoedarmo, Soepomo, et al. (1979). Tingkat Tutur Bahasa Jawa. Jakarta: Pusat Pembinaan dan Pengembangan Bahasa.

Poedjosoedarmo, Soepomo, et al. (1982). Kedudukan dan Fungsi Bahasa Jawa. Yogyakarta: Balai Penelitian Bahasa.

Poedjosoedarmo, Soepomo. (1968). Javanese Speech Levels. in Jurnal Indonesia, No. 6 (Oct.), Southeast Asia Program, Cornell University. p. 54-81.

Poedjosoedarmo, Soepomo. (1978). Kode dan Alih Kode. in Jurnal Balai Penelitian Bahasa. Widyaparwa No. 15. Yogyakarta: Balai Penelitian Bahasa.

Poedjosoedarmo, Soepomo. (2001). Filsafat Bahasa. Surakarta: Muhammadiyah University Press.

Poedjosoedarmo, Soepomo. (2017). Language Propriety in Javanese. in Journal of Language and Literature, Vol. 17, No. 1.

Searl, J.R. (1969). Speech Acts: An Essay in the Philosophy of Language. Cambridge: Cambridge University Press.

Sudaryanto. (1993). Metode dan Aneka Teknik Analisis Bahasa: Pengantar Penelitian Wahana Kebudayaan secara Linguistis. Yogyakarta: Duta Wacana University Press.

Sugiyono. (2012). Metode Penelitian Pendidikan: Pendekatan Kuantitatif, Kualitatif, dan $R \& D$. Bandung: Alfabeta.

Wardhaugh, Ronald. (1988). An Introduction to Sociolinguistics. Oxford: Basil Blackwell. 